Supplement of The Cryosphere, 14, 3329-3347, 2020

https://doi.org/10.5194/tc-14-3329-2020-supplement

(C) Author(s) 2020. This work is distributed under

the Creative Commons Attribution 4.0 License.

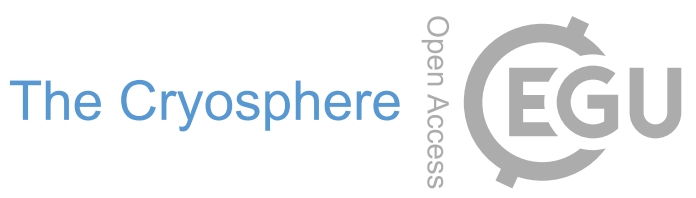

(c) (1)

Supplement of

\title{
Frazil ice growth and production during katabatic wind events in the Ross Sea, Antarctica
}

\section{Lisa Thompson et al.}

Correspondence to: Brice Loose (bloose@uri.edu)

The copyright of individual parts of the supplement might differ from the CC BY 4.0 License. 
1 Section S1: Estimation of frazil ice concentration using temperature anomalies

3 To measure the amount of the temperature anomaly:

$$
\mathrm{Q}_{\mathrm{excess}}=\rho C_{p}^{W} \Delta T
$$

Heat content per volume of water can be quantified as $Q$ and calculated (Talley et al 2011).

$$
Q=\rho C_{p}^{W} T
$$

To find the heat content in the temperature anomaly, or excess heat, equation S1.1 can be substituted into equation S2.2.

$\rho=$ seawater density $\left(\mathrm{kg} \mathrm{m}^{-3}\right)$

$C_{p}^{W}=$ specific heat capacity $\left(\mathrm{J} \mathrm{kg}^{-1} \mathrm{~K}^{-1}\right)$

$\mathrm{T}=$ temperature of the water (degrees $\mathrm{K}$ )

$\mathrm{Q}=$ heat content per volume $\left(\mathrm{J} \mathrm{m}^{-3}\right)$

\section{8}

$39 \quad C_{i c e}^{T}=\frac{Q_{\text {excesl }}^{\text {total }}}{L_{f} z_{T}}$

$$
\begin{aligned}
& Q_{\text {excess }}^{\text {total }}=\int_{z=0}^{z=z_{T}} \rho C_{p}^{W} \Delta T d z \\
& z_{T}=\text { depth of the temperature Anomaly }(\mathrm{m}) \\
& Q_{\text {excess }}^{\text {total }}=\text { total amount of residual heat in the water column }\left(\mathrm{Jm}^{-2}\right)
\end{aligned}
$$

The concentration of frazil ice is estimated by applying the Latent heat of formation as a conversion factor to the calculated internal energy $\left(Q_{\text {excess }}^{\text {total }}\right)$ :

$$
C_{i c e}^{T}=\frac{Q_{\text {excesl }}^{\text {total }}}{L_{f} z_{T}}
$$


$\mathrm{L}_{\mathrm{f}}=$ latent heat of fusion $=3.34 \times 10^{5} \mathrm{~J} \mathrm{~kg}^{-1}$

$z_{T}=$ depth of the temperature anomaly $(\mathrm{m})$

Table S1: Data for frazil ice concentration using temperature anomalies. Includes Baseline Temperature,

46 Depth of the Temperature anomaly, Average Specific Heat Capacity (over the range of the anomaly),

47 Residual heat, and Estimation of Mass concentration of Ice.

\begin{tabular}{|l|l|l|l|l|l|}
\hline Station & \multicolumn{1}{|c|}{$T_{b}$} & \multicolumn{1}{|c|}{$z_{T}$} \\
$(\mathrm{~m})$ & $\begin{array}{c}C_{p}^{W} \\
\left(\mathrm{~J} \mathrm{~kg}^{-1} \mathrm{~K}^{-1}\right)\end{array}$ & $\begin{array}{l}Q_{\text {excess }}^{\text {total }} \\
\left(\mathrm{KJ} \mathrm{m}^{-2}\right)\end{array}$ & $\begin{array}{c}C_{\text {ice }}^{T} \\
\left(\mathrm{~kg} \mathrm{~m}^{-3}\right)\end{array}$ \\
\hline 25 & -1.910 & 11.34 & 3988 & 183 & $48 \times 10^{-3}$ \\
\hline 26 & -1.912 & 24.73 & 3988 & 122 & $14 \times 10^{-3}$ \\
\hline 27 & -1.914 & 15.45 & 3988 & 115 & $22 \times 10^{-3}$ \\
\hline 28 & -1.915 & 15.52 & 3988 & 92 & $18 \times 10^{-3}$ \\
\hline 30 & -1.906 & 11.34 & 3989 & 82 & $22 \times 10^{-3}$ \\
\hline 32 & -1.914 & 11.33 & 3988 & 121 & $25 \times 10^{-3}$ \\
\hline $33 *$ & -1.913 & --- & 3988 & --- & $32 \times 10^{-3}$ \\
\hline 34 & -1.909 & 13.40 & 3988 & 42 & --- \\
\hline 35 & -1.910 & 19.58 & 3988 & 230 & $35 \times 10^{-3}$ \\
\hline 40 & -1.885 & 20.61 & 3991 & 233 & $33 \times 10^{-3}$ \\
\hline
\end{tabular}

* Station 33 does not have a measurable temperature anomaly, but has a measurable salinity anomaly so 
54 Salt

55

56

57

58

59

60

61

62

63

64

65

\section{Salt}

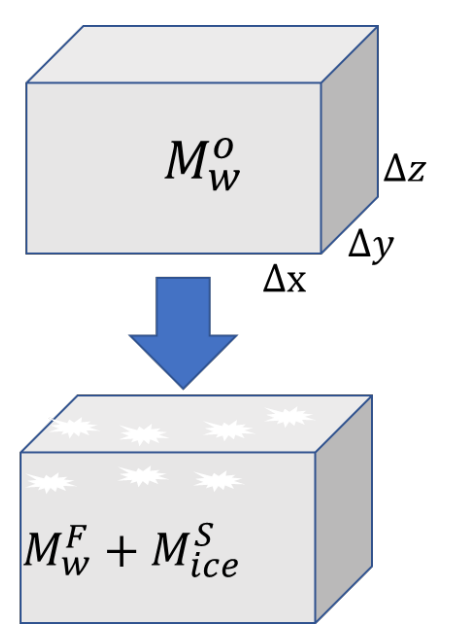

Conservation of Mass of Water:

$M_{W}^{O}=M_{W}^{F}+M_{i c e}^{S}$

$M_{W}^{O}=$ Mass of Water originally

$M_{W}^{F}=$ Mass of Water after freezing

$=$ Mass of Water as Ice

66

67

Figure S2.1: 1-D box model of the Conservation of Mass of Water.

68

69 Conservation of Mass of Salt:

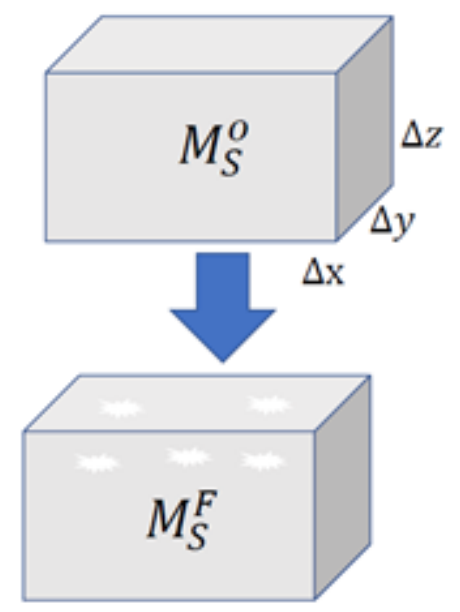

$M_{S}^{O}=M_{S}^{F}$

Salinity Equations:

$M_{S}^{O}=S_{b} M_{W}^{O}$

$M_{S}^{F}=S_{o b s} M_{W}^{F}$

$M_{S}^{O}=$ Mass of Salt Initially

$M_{S}^{F}=$ Mass of Salt, Final

$S_{b}=$ Original/Baseline Salinity

81 $\quad S_{o b s}=$ Salinity Final/Observed

Figure S2.2: 1-D box model of the Conservation of Mass of Salt.

85 Combine the Conservation of Mass of Salt and Salinity Equations, equations S2.2 and S2.3:

$86 \quad M_{S}^{F}=S_{b} M_{O}^{W}$

87

88 Combine S2.5 with Conservation of the Mass of Water S2.1:

$89 M_{S}^{F}=S_{b}\left(M_{W}^{F}+M_{i c e}^{S}\right)=S_{b} M_{W}^{F}+S_{b} M_{i c e}^{S}$

90

91 Combine the Conservation of Mass of Water and the Conservation of Mass of Salt, equations

92 S2.1 and S2.4: 
$93 \quad M_{s}^{F}=S_{o b s}\left(M_{W}^{O}-M_{i c e}^{S}\right)=S_{o b s} M_{W}^{O}-S_{o b s} M_{i c e}^{S}$

94

95 Combine equations from S2.6 and S2.7:

$96 S_{b} M_{W}^{F}+S_{b} M_{i c e}^{S}=S_{o b s} M_{W}^{O}-S_{o b s} M_{i c e}^{S}$

97

98 Combine equations S2.1 and S2.8:

$99 S_{b}\left(M_{W}^{O}-M_{i c e}^{S}\right)+S_{b} M_{i c e}^{S}=S_{o b s} M_{W}^{O}-S_{o b s} M_{i c e}^{S}$

$100 S_{b} M_{W}^{O}-S_{b} M_{i c e}^{S}+S_{b} M_{i c e}^{S}=S_{o b s} M_{W}^{O}-S_{o b s} M_{i c e}^{S}$

101

102

Rearrange equation S2.9 to isolate, $M_{W}^{O}$ and $M$ :

$103 M_{W}^{O}\left(S_{b}-S_{o b s}\right)=M_{i c e}^{S}\left(S_{b}-S_{b}-S_{o b s}\right)$

104

105 Solved equation S2.10 for $M_{i c e}^{S}$ :

$106 M_{i c e}^{S}=\frac{\left(S_{o b s}-S_{b}\right)}{S_{o b s}} M_{W}^{O}$

107

108

109

110

111

112

113

114

115

116

117

118

119

120

121

122

123

124

125

126

127

128

129

130

131 
To measure the amount of the salinity anomaly:

$$
\Delta S=S_{o b s}-S_{b}
$$
$S_{b}=$ baseline or far field salinity ( 10 meter average below anomaly) $\left(\mathrm{g} \mathrm{kg}^{-1}\right)$ $S_{o b s}=$ in-situ absolute salinity within the anomaly $\left(\mathrm{g} \mathrm{kg}^{-1}\right)$ $\Delta \mathrm{S}=$ salinity anomaly $\left(\mathrm{g} \mathrm{kg}^{-1}\right)$

$$
M_{i c e}^{S}=\frac{\left(S_{o b s}-S_{b}\right)}{S_{o b s}} M_{W}^{O}
$$

\section{Substitute equation S3.1 into equation S3.2:}

$$
M_{i c e}^{S}=\frac{\Delta S}{S_{o b s}} M_{W}^{O}
$$

To find the total mass of frazil ice $\left(M_{i c e}^{S}\right)$ in the water column, equation S3.2 is solved for each depth step of the anomaly and then the integral is taken to find the total mass of ice. As shown in equation S3.4, the mass of water originally $\left(M_{W}^{O}\right)$ uses the same assumed baseline density $\left(\rho_{b}=\right.$ $1028 \mathrm{~kg} \mathrm{~m}^{-3}$ ) at each depth step. This allows for equation the salt ratio is taken at each step of the depth range of the anomaly and multiplied by the mass of water initially at that step. The integral is then taken of the entire depth range of the anomaly.

$$
M_{i c e}^{S}=\rho_{b} \times \int_{Z=0}^{Z=z_{S}} \frac{\Delta S}{S_{o b s}} d z
$$

$z_{S}=$ depth of the Anomaly (m)

$M_{i c e}^{S}=$ total mass of frazil ice $\left(\mathrm{kg} \mathrm{m}^{-2}\right)$ from salinity derivation

$M_{W}^{O}=$ Mass of Water initially at each step of the integral $\left(\mathrm{kg} \mathrm{m}^{-2}\right)$

$\rho_{b}=1028 \mathrm{~kg} \mathrm{~m}^{-3}=$ Assumed baseline/initial density, calculated using $S_{b}$.

$$
C_{I c e}^{S}=\frac{M_{I c e}^{S}}{z_{S}}
$$

$$
\text { Conc }_{\text {Ice }}^{\text {salt }}=\text { Concentration of frazil ice }=\mathrm{kg} \mathrm{m}^{-3}
$$


$M_{i c e}^{S}=$ total mass of frazil ice $\left(\mathrm{kg} \mathrm{m}^{-2}\right)$ from salinity derivation

$z_{S}=$ depth of the Anomaly (m)

Table S2: Data for frazil ice concentration using salinity anomalies. Includes Baseline Salinity, Depth of the salinity anomaly, mass of water assumed to be initially present, Estimation of Mass of Ice, and Concentration of Ice.

\begin{tabular}{|c|c|c|c|c|}
\hline Station & $\begin{array}{c}S_{b} \\
\left(\mathrm{~g} \mathrm{~kg}^{-1}\right)\end{array}$ & $\begin{array}{l}z_{S} \\
(\mathrm{~m})\end{array}$ & $\begin{array}{c}M_{i c e}^{S} \\
\left(\mathrm{~kg} \mathrm{~m}^{-2}\right)\end{array}$ & $\begin{array}{c}C_{i c e}^{S} \\
\left(\mathrm{~kg} \mathrm{~m}^{-3}\right)\end{array}$ \\
\hline 25 & 34.861 & 13.40 & 0.898 & $67 \times 10^{-3}$ \\
\hline 26 & -- & -- & & -- \\
\hline 27 & 34.962 & 41.22 & 1.917 & $46 \times 10^{-3}$ \\
\hline 28 & 34.867 & 17.52 & 0.385 & $21 \times 10^{-3}$ \\
\hline 29 & 34.730 & 21.64 & 1.106 & $51 \times 10^{-3}$ \\
\hline 30 & 34.870 & 36.07 & 3.799 & $105 \times 10^{-3}$ \\
\hline 32 & 34.849 & 47.40 & 5.636 & $119 \times 10^{-3}$ \\
\hline 33 & 34.863 & 22.67 & 0.646 & $29 \times 10^{-3}$ \\
\hline 34 & 34.778 & 19.58 & 1.35 & $89 \times 10^{-3}$ \\
\hline 35 & 34.798 & 14.43 & 3.84 & $266 \times 10^{-3}$ \\
\hline 40 & 34.293 & 18.55 & 0.245 & $13 \times 10^{-3}$ \\
\hline
\end{tabular}


Estimating the maximum dissipation length scale, $d_{\max }$ via Monin-Obukhov length $\left(L_{M-o}\right)$ (Monin-Obukhov, 1954):

$$
L_{M-O}=-\frac{u_{*}^{3}}{k \beta g w \overline{\Delta S}}
$$

$u_{*}=$ friction velocity, calculated in $\mathrm{S} .5=\mathrm{m} \mathrm{s}^{-1}$ $g=$ gravitational acceleration $=9.81 \mathrm{~m} \mathrm{~s}^{-2}$

$197 \quad L_{M-O}=-\frac{u_{*}^{3}}{k \beta g w \overline{\Delta S}}=-\frac{\frac{m^{3}}{s^{3}}}{k \frac{k g}{g} \frac{m}{s^{2}} \frac{m g}{s k g}}=\frac{\frac{m^{3}}{s^{3}}}{\frac{m^{2}}{s^{3}}}=m$

198 Table S3: Data for Monin-Obukhov Length scale calculations.

\begin{tabular}{|l|l|l|l|}
\hline Station & $\overline{\Delta \mathrm{S}}\left(\mathrm{g} \mathrm{kg}^{-1}\right)$ & $\mathrm{u}_{*}\left(\mathrm{~m} \mathrm{~s}^{-1}\right)$ & \multicolumn{1}{|c|}{$\mathrm{L}_{\mathrm{M}-\mathrm{O}}(\mathrm{m})$} \\
\hline 25 & $2.2 \times 10^{-3}$ & $2.4 \times 10^{-2}$ & 141 \\
\hline 26 & --- & $2.4 \times 10^{-2}$ & -- \\
\hline 27 & $1.5 \times 10^{-3}$ & $2.2 \times 10^{-2}$ & 151 \\
\hline 28 & $7.23 \times 10^{-4}$ & $1.2 \times 10^{-2}$ & 54 \\
\hline 29 & $1.7 \times 10^{-3}$ & $1.9 \times 10^{-2}$ & 80 \\
\hline 30 & $3.5 \times 10^{-3}$ & $2.4 \times 10^{-2}$ & 83 \\
\hline 32 & $4.0 \times 10^{-3}$ & $3.9 \times 10^{-2}$ & 198 \\
\hline 33 & $9.1 \times 10^{-4}$ & $1.6 \times 10^{-2}$ & 98 \\
\hline 34 & $2.3 \times 10^{-3}$ & $1.9 \times 10^{-2}$ & 66 \\
\hline 35 & $8.8 \times 10^{-3}$ & $1.4 \times 10^{-2}$ & 6 \\
\hline 40 & $1.4 \times 10^{-3}$ & $2.2 \times 10^{-2}$ & 175 \\
\hline
\end{tabular}
averaged over the depth range of the anomaly $=7.87 \times 10^{-4}$ $k=$ von Karman constant $=0.41$ 


\section{Section S5: Wind Analysis}

$$
\begin{aligned}
U_{10}= & U_{P} \frac{\ln \left(\frac{z}{z_{0}}\right)}{\ln \left(\frac{z_{P}}{z_{o}}\right)} \\
& z_{0}=\text { Roughness Class }=0.0002 \mathrm{~m} \\
& z_{P}=\text { Reference height }=24 \mathrm{~m} \\
& z=\text { Desired height }=10 \mathrm{~m}
\end{aligned}
$$

209

210

Average environmental values from NB Palmer used as inputs for COARE 3 to calculate the Drag Coefficient $\left(C_{D}\right)$ :

average $U_{10}=$ average wind speed $=9.8 \mathrm{~m} \mathrm{~s}^{-1}$

average $T_{\text {air }}=$ average air temperature $=-18.7^{\circ} \mathrm{C}$

average $R H=$ average relative humidity $=78.3 \%$ average $P=$ average air pressure $=979.4$ milli-bar average $T_{\text {water }}=$ average water temperature $=-1.74{ }^{\circ} \mathrm{C}$ average $R_{S}=$ average shortwave radiation $=-3.56 \mathrm{~W} \mathrm{~m}^{-2}$ average $R_{L}=$ average longwave radiation $=201.2 \mathrm{~W} \mathrm{~m}^{-2}$ average $L$ at $=$ average latitude $=-75^{\circ}$

Average wave height and wave period of the 04 May SWIFT deployment used the wave as inputs for COARE 3 to calculate the wave dependent Drag Coefficient $\left(C_{D}\right)$ :

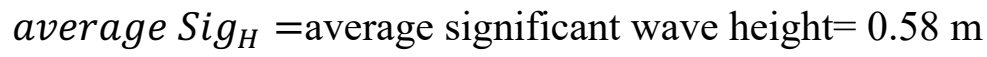
average $T=$ average wave period $=4.6$ seconds

The average phase speed $\left(c_{p}\right)$ was calculated from the wave period (T)using the formula for deep water dispersion:

$$
c_{p}=\frac{g}{2 \pi} T
$$

$c_{p}=$ average phase speed $=7.2 \mathrm{~m} \mathrm{~s}^{-1}$

$g=$ gravity, $9.81 \mathrm{~m} \mathrm{~s}^{-2}$

average $T=$ average wave period $=4.6 \mathrm{~s}$

Based on the average values, the Drag Coefficient $\left(C_{D}\right)$ was found to be: $C_{D}=1.525 \times 10^{-3}$

The wind stress, $\tau$, was calculated for each CTD station based on the extrapolated wind speed at 10 meters, $U_{10}$, average air density, and average drag coefficient:

$$
\tau=C_{D} \rho_{\text {air }} U_{10}^{2}
$$


240 above.

241

242 Using wind stress, we derived the friction velocity $\left(u_{*}\right)$ at the air-sea interface using the wind

243 stress and water density, $\rho_{\text {water }}$.

244

$$
u_{*}=\sqrt{\frac{\tau}{\rho_{\text {water }}}}
$$

245

246

247

248

249

Table S4: Data for wind analysis summarized in Supplemental 5.

\begin{tabular}{|l|l|l|l|l|l|}
\hline Station & \multicolumn{1}{|c|}{$\begin{array}{c}U_{P} \\
\left(\mathrm{~m} \mathrm{~s}^{-1}\right)\end{array}$} & \multicolumn{1}{|c|}{$\begin{array}{c}U_{10} \\
\left(\mathrm{~m} \mathrm{~s}^{-1}\right)\end{array}$} & \multicolumn{1}{c|}{$\begin{array}{c}\tau \\
\left(\mathrm{kg} \mathrm{m}^{-1} \mathrm{~s}^{-2}\right)\end{array}$} & $\begin{array}{c}\rho_{\text {water }} \\
\left(\mathrm{kg} \mathrm{m}^{-3}\right)\end{array}$ & \multicolumn{1}{c|}{$\begin{array}{c}u_{*} \\
\left(\mathrm{~m} \mathrm{~s}^{-1}\right)\end{array}$} \\
\hline 25 & 12.72 & 11.39 & 0.582 & 1028.06 & $2.4 \times 10^{-2}$ \\
\hline 27 & 12.31 & 10.68 & 0.512 & 1028.14 & $2.2 \times 10^{-2}$ \\
\hline 28 & 11.54 & 5.89 & 0.156 & 1028.02 & $1.2 \times 10^{-2}$ \\
\hline 29 & 6.37 & 8.90 & 0.355 & 1027.94 & $1.9 \times 10^{-2}$ \\
\hline 30 & 12.43 & 11.50 & 0.594 & 1028.12 & $2.4 \times 10^{-2}$ \\
\hline 32 & 20.43 & 18.90 & 1.603 & 1028.16 & $3.9 \times 10^{-2}$ \\
\hline 33 & 8.37 & 7.74 & 0.269 & 1028.05 & $1.6 \times 10^{-2}$ \\
\hline 34 & 9.95 & 9.21 & 0.380 & 1027.97 & $1.9 \times 10^{-2}$ \\
\hline 35 & 7.15 & 6.61 & 0.196 & 1027.97 & $1.4 \times 10^{-2}$ \\
\hline 40 & 11.59 & 10.72 & 0.516 & 1027.59 & $2.2 \times 10^{-2}$ \\
\hline
\end{tabular}

$u_{*}=$ friction velocity

$\rho_{\text {water }}=$ density of water 
259 Using the $L_{M-O}$, turbulent kinetic energy $(\varepsilon)$ can be applied to find the minimum time scale for 260 mixing:

$261 t=\frac{\pi d}{v_{*}} \approx \frac{d}{(\varepsilon d)^{\frac{1}{3}}} \approx\left(\frac{L_{M-O}^{2}}{\varepsilon}\right)^{\frac{1}{3}}$

$$
t=\text { timescale }=\mathrm{s}
$$

264 $\varepsilon=$ turbulent kinetic energy dissipation $=1.85 \times 10^{-5} \mathrm{~m}^{2} \mathrm{~s}^{-3}$ $L_{M-O}=$ Monin-Obukhov Length $=\mathrm{m}$

$268 r_{\text {ice }}=\frac{c_{i c e}^{S} z_{S}}{t \rho_{\text {ice }}}=\mathrm{m} \mathrm{d}^{-1}$ $t=$ timescale $=\mathrm{d}$

273 $\rho_{\text {ice }}=920 \mathrm{~kg} \mathrm{~m}^{-3}$

274

275

276

277

278

279

280

281

282

283

284

285

286

287 
Table S5: Calculation of time scale and production rate.

\begin{tabular}{|l|l|l|l|l|l|c|}
\hline Station & \multicolumn{1}{|c|}{$\begin{array}{c}C_{\text {ice }}^{S} \\
\left(\mathrm{~kg} \mathrm{~m}^{-3}\right)\end{array}$} & $\begin{array}{c}L_{M-O} \\
(\mathrm{~m})\end{array}$ & $\begin{array}{c}c \\
\left(\mathrm{~m}^{2} \mathrm{~s}^{-3}\right)\end{array}$ & $\begin{array}{c}\mathrm{t} \\
(\mathrm{min})\end{array}$ & $\begin{array}{c}r_{\text {ice }} \\
\left(\mathrm{cm} \mathrm{d}^{-1}\right)\end{array}$ & $\begin{array}{c}r_{\text {ice } 95 \% \mathrm{CI}} \\
\left(\mathrm{cm} \mathrm{d}^{-1}\right)\end{array}$ \\
\hline 25 & $67 \times 10^{-3}$ & 141 & $9.648 \times 10^{-05}$ & 9.8 & 14 & {$[10-20]$} \\
\hline 26 & -- & --- & $7.191 \times 10^{-05}$ & --- & --- & -- \\
\hline 27 & $46 \times 10^{-3}$ & 151 & $8.188 \times 10^{-05}$ & 10.9 & 28 & {$[20-37]$} \\
\hline 28 & $21 \times 10^{-3}$ & 54 & $1.622 \times 10^{-05}$ & 9.4 & 6 & {$[4-10]$} \\
\hline 29 & $51 \times 10^{-3}$ & 80 & $5.375 \times 10^{-05}$ & 8.2 & 21 & {$[15-28]$} \\
\hline 30 & $105 \times 10^{-3}$ & 83 & $3.771 \times 10^{-05}$ & 9.5 & 63 & {$[45-88]$} \\
\hline 32 & $119 \times 10^{-3}$ & 197 & $3.466 \times 10^{-04}$ & 8.0 & 110 & {$[67-181]$} \\
\hline 33 & $29 \times 10^{-3}$ & 98 & $2.844 \times 10^{-05}$ & 11.6 & 9 & {$[5-13]$} \\
\hline 34 & $89 \times 10^{-3}$ & 66 & $6.397 \times 10^{-05}$ & 6.8 & 31 & {$[23-42]$} \\
\hline 35 & $266 \times 10^{-3}$ & 6 & $2.343 \times 10^{-05}$ & 2.0 & 302 & {$[200-456]$} \\
\hline 40 & $13 \times 10^{-3}$ & 175 & $9.603 \times 10^{-05}$ & 11.7 & 3 & {$[2-5]$} \\
\hline
\end{tabular}

296

297

298

299

300

301

302

303

304

305

306

307

308

309

310

311

312

313 


\section{Section S7: Seasonal Ice Production Estimate and Comparison}

$$
Q_{s}=c_{p}^{A} \rho_{a} C_{s} u_{10}\left(T_{b}-T_{a}\right)
$$
in supplemental 5

$$
c_{p}^{A}=1.003 \mathrm{~kJ} \mathrm{~kg}^{-1} \mathrm{~K}^{-1} \text {, the specific heat capacity of air at }-23{ }^{\circ} \mathrm{C}
$$

$\rho_{a=}=$ density of air $=1.34 \mathrm{~kg} \mathrm{~m}^{-3}$ calculated using averages from NB Palmer summarized $C_{s}=1.297 \times 10^{-3}$, the heat transfer coefficient over snow, ice, water, calculated using the COARE 3.0 code (Fairall et al, 2003)

$\mathrm{T}_{\mathrm{b}}=$ sea surface temperature/ baseline or far field temperature (10 meter average below anomaly) $\left({ }^{\circ} \mathrm{C}\right)$

$$
T_{a}=\text { air temperature from NB Palmer }\left({ }^{\circ} \mathrm{C}\right)
$$

\begin{tabular}{|c|c|c|c|c|c|}
\hline Station & $T_{b} \quad\left({ }^{\circ} \mathrm{C}\right)$ & $T_{a} \quad\left({ }^{\circ} \mathrm{C}\right)$ & $U_{10}\left(\mathrm{~m} \mathrm{~s}^{-1}\right)$ & $Q_{S}\left(\mathrm{~W} \mathrm{~m}^{-2}\right)$ & $r_{\text {ice }}\left(\mathrm{cm} \mathrm{d}^{-1}\right)$ \\
\hline 25 & -1.910 & -16.58 & 11.77 & 301 & 14 \\
\hline 27 & -1.914 & -15.83 & 10.68 & 259 & 28 \\
\hline 28 & -1.915 & -15.93 & 5.89 & 144 & 6 \\
\hline 29 & -1.906 & -24.71 & 8.90 & 354 & 21 \\
\hline 30 & -1.916 & -25.6 & 11.50 & 475 & 63 \\
\hline 32 & -1.914 & -24.95 & 18.90 & 759 & 110 \\
\hline 33 & -1.913 & -21.56 & 7.74 & 265 & 9 \\
\hline 34 & -1.909 & -19.39 & 9.21 & 281 & 31 \\
\hline
\end{tabular}

\section{Sensible Heat Flux, and Production Rate}




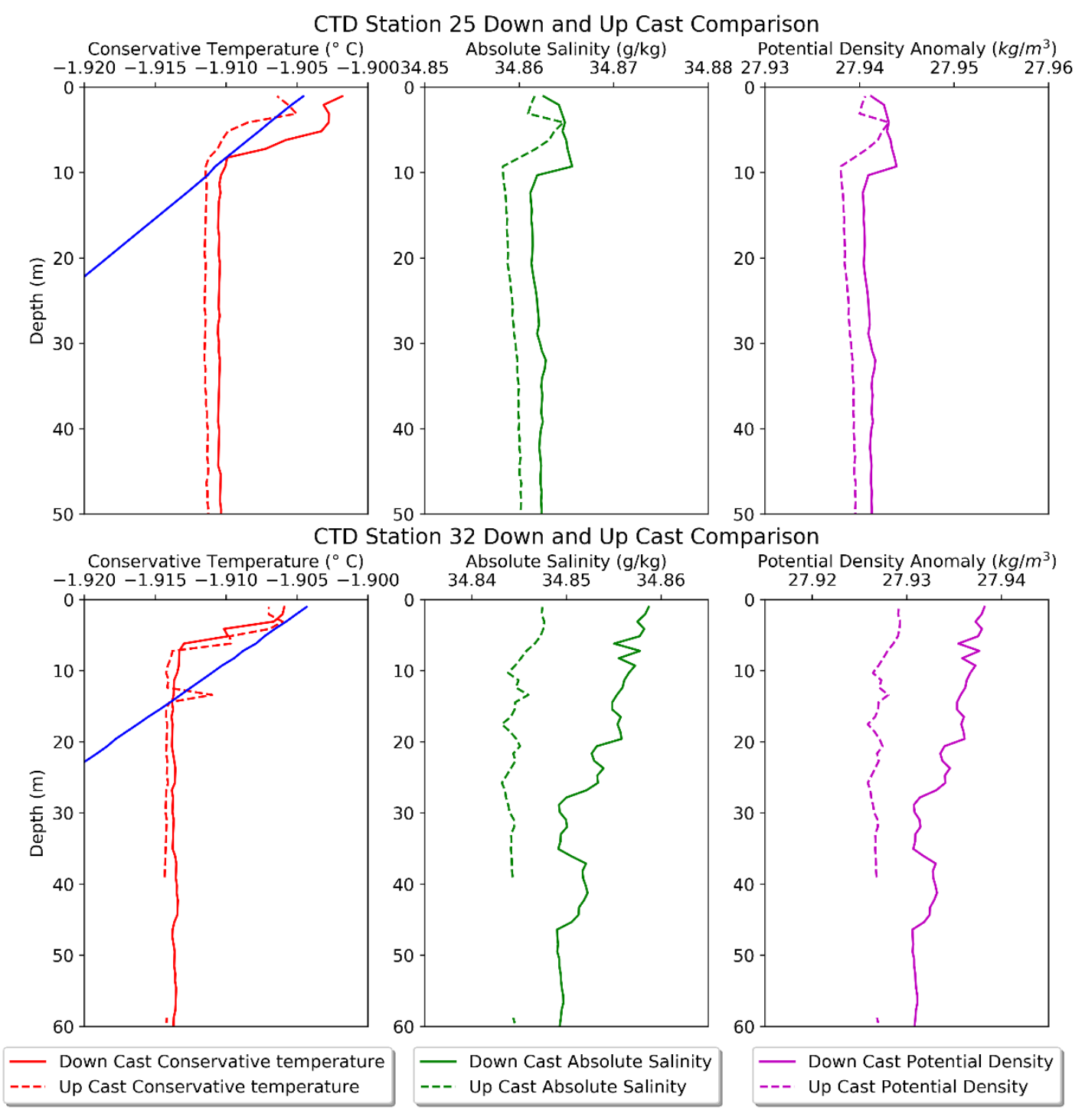

Supplemental Figure 1: Comparison of Down and Up Cast Profiles from CTD Station 25 and Station 32. Conservative Temperature (red dashed line) for Station 25, resulting in a smaller up cast anomaly. For Station 25 the same trend is seen in salinity and attributed to the wake of the CTD. For Station 32, the Conservative Temperature profiles are very similar, however of note there is missing data between 40-60 meters that is attributed to the wake of the CTD. There is a notable difference in the Absolute salinity, however there is still presence of an anomaly/ 


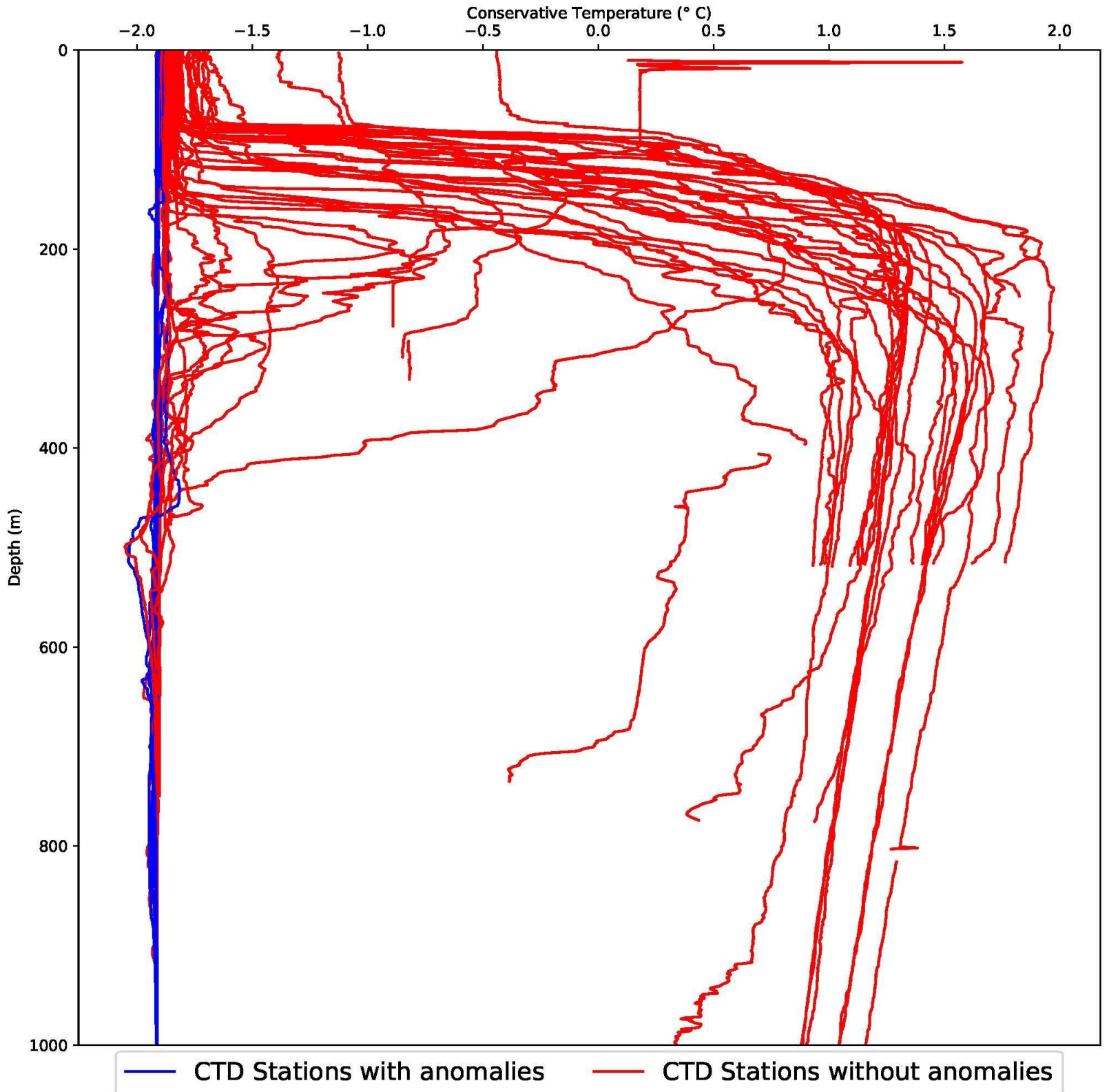

Supplemental Figure 2: Conservative Temperature profiles of all 57 (of 58) PIPERS CTD stations. One CTD profile acquired north of the Polar Front was not included here, since its temperature range lie outside the range chosen here. Those CTD profiles from TNBP and RSP that indicated frazil ice production are plotted in blue, while profiles without frazil ice anomalies are plotted in red. In addition to large mixed layers, the polynya profiles also show the coldest temperatures. 

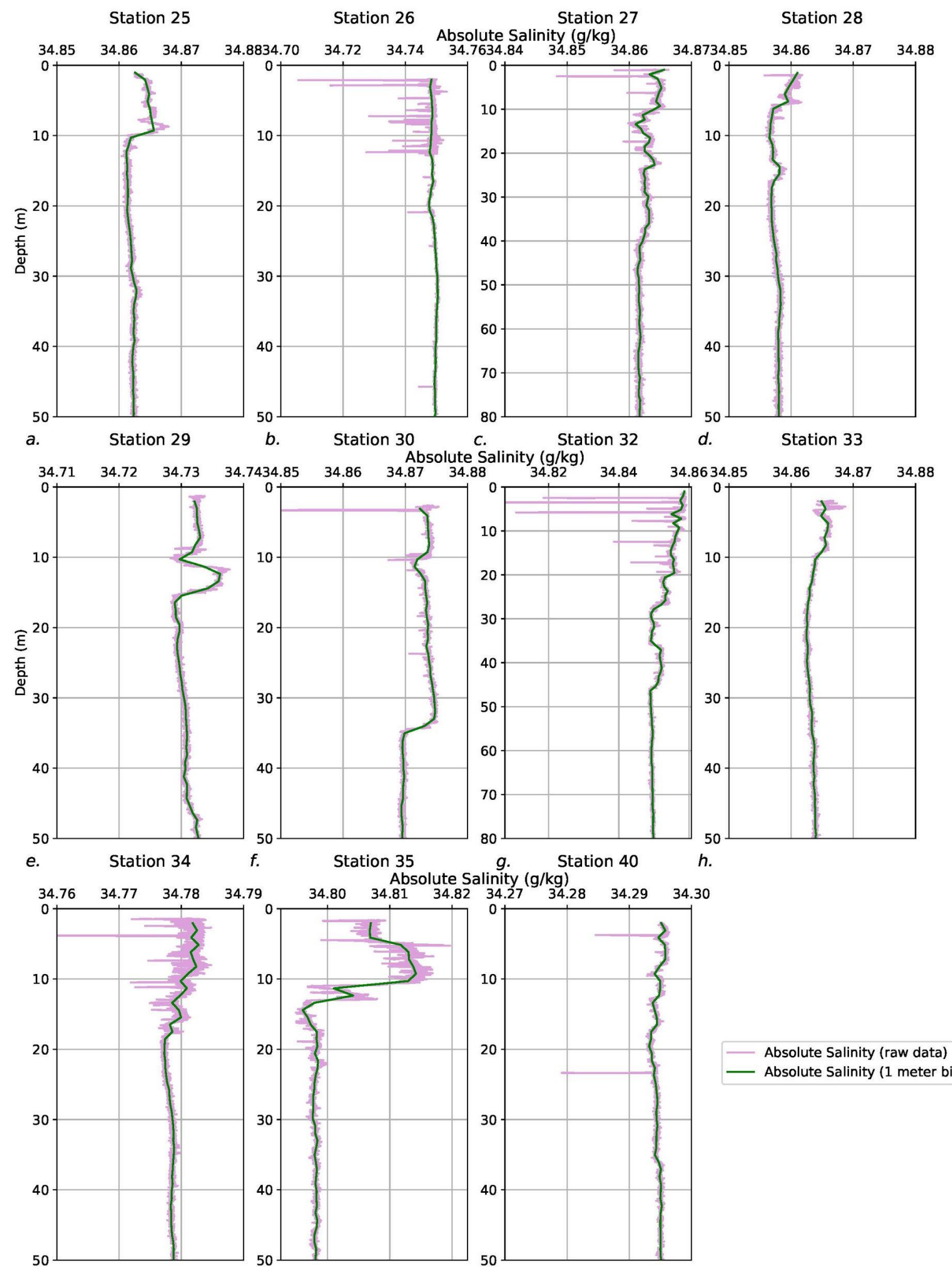

i.
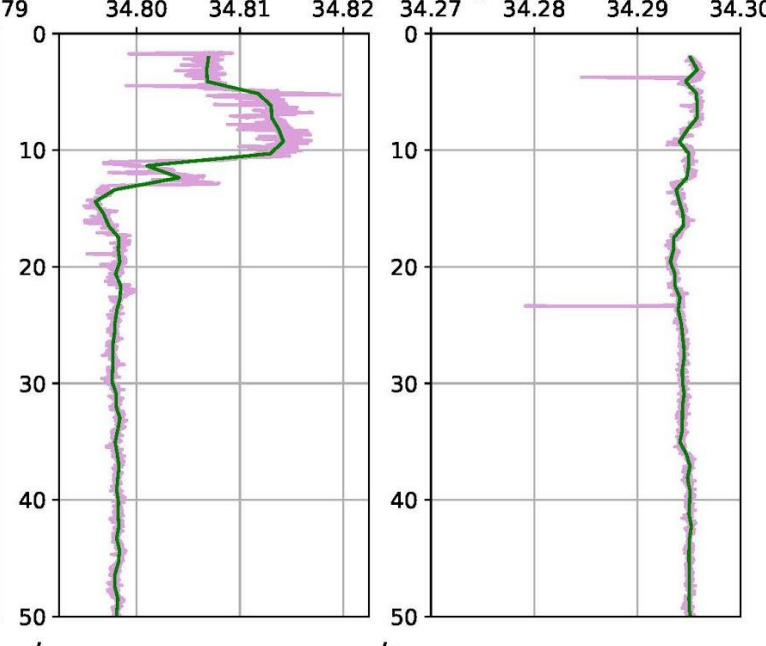

j.

$k$.

- Absolute Salinity (raw data) — Absolute Salinity (1 meter bins)

Supplemental Figure 3: Absolute Salinity plotted from raw conductivity data and from 1 meter binned data for the 
359 plotted in purple, shows varying levels of noise in the signal and spikes of lesser magnitude values. This noise and 360 the spikes in the data likely due to frazil ice crystal interference. Values of spikes extending off the plot: $\mathrm{f}: 34.670 \mathrm{~g}$ $361 \mathrm{~kg}^{-1}$; g: $34.800 \mathrm{~g} \mathrm{~kg}^{-1}$; i: $34.740 \mathrm{~g} \mathrm{~kg}^{-1}$. Plots b, c, i, j display more noise than the other plots. The 1-meter bin data, 362 plotted in green, does not follow the spike excursions, indicating that binning the minimizes or removes the effects 363 of the noise and spikes.

364

365

366 


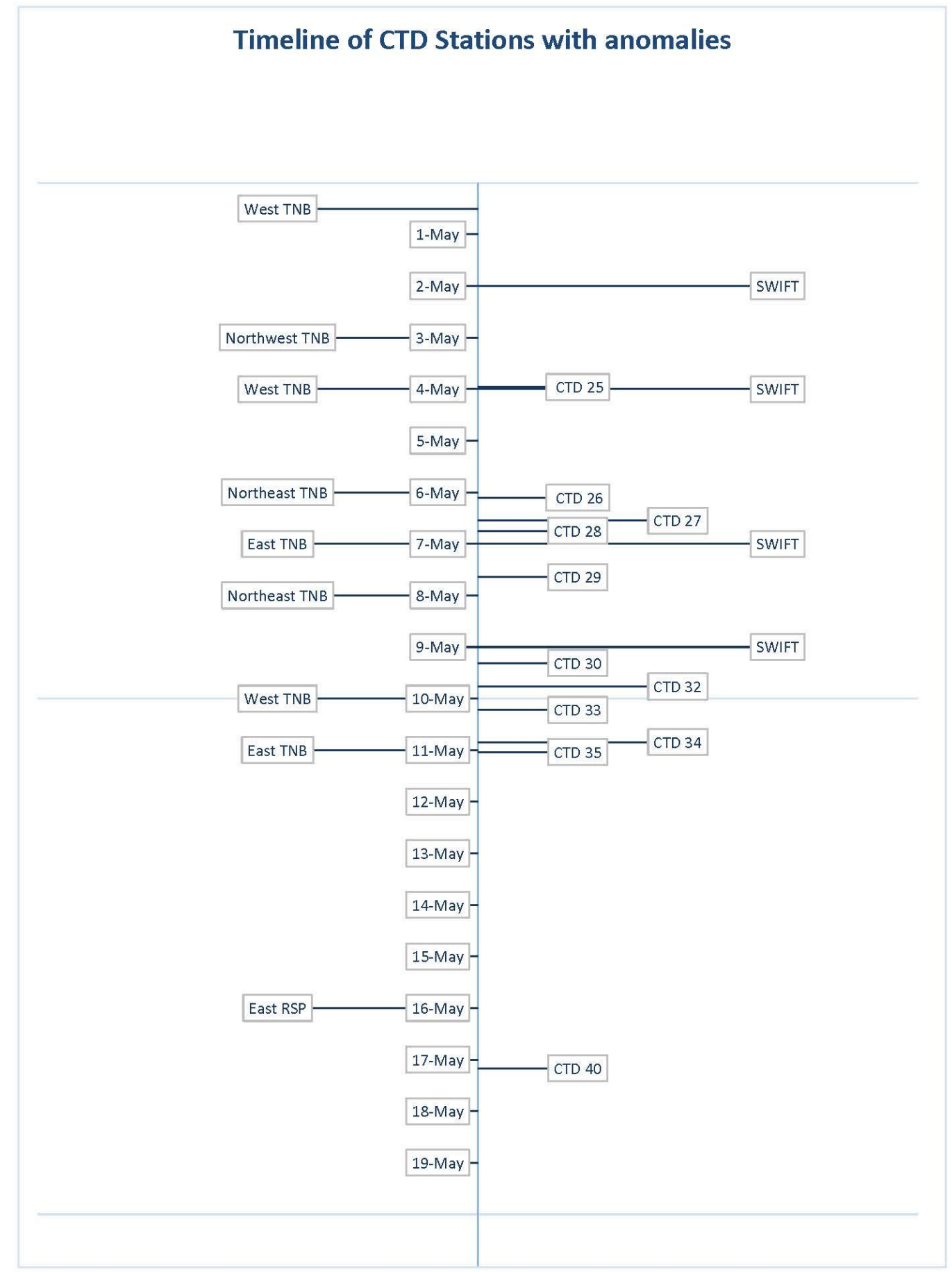

368 Supplemental Figure 4: Timeline of TNBP and RSP CTD casts and SWIFT deployments. A timeline of CTD and 369 SWIFT deployments while in TNBP and RSP. To the left of the date, the geographic region is noted. This indicates 370 when NB Palmer entered that portion of each polynya. The NB Palmer was in TNBP from May 1 to May 13. The 
371 NB Palmer was in the RSP from May 16 to May 18. To the right of the date the CTD stations with anomalies and 372 SWIFT deployments are shown. All of the SWIFT deployments where in TNBP.

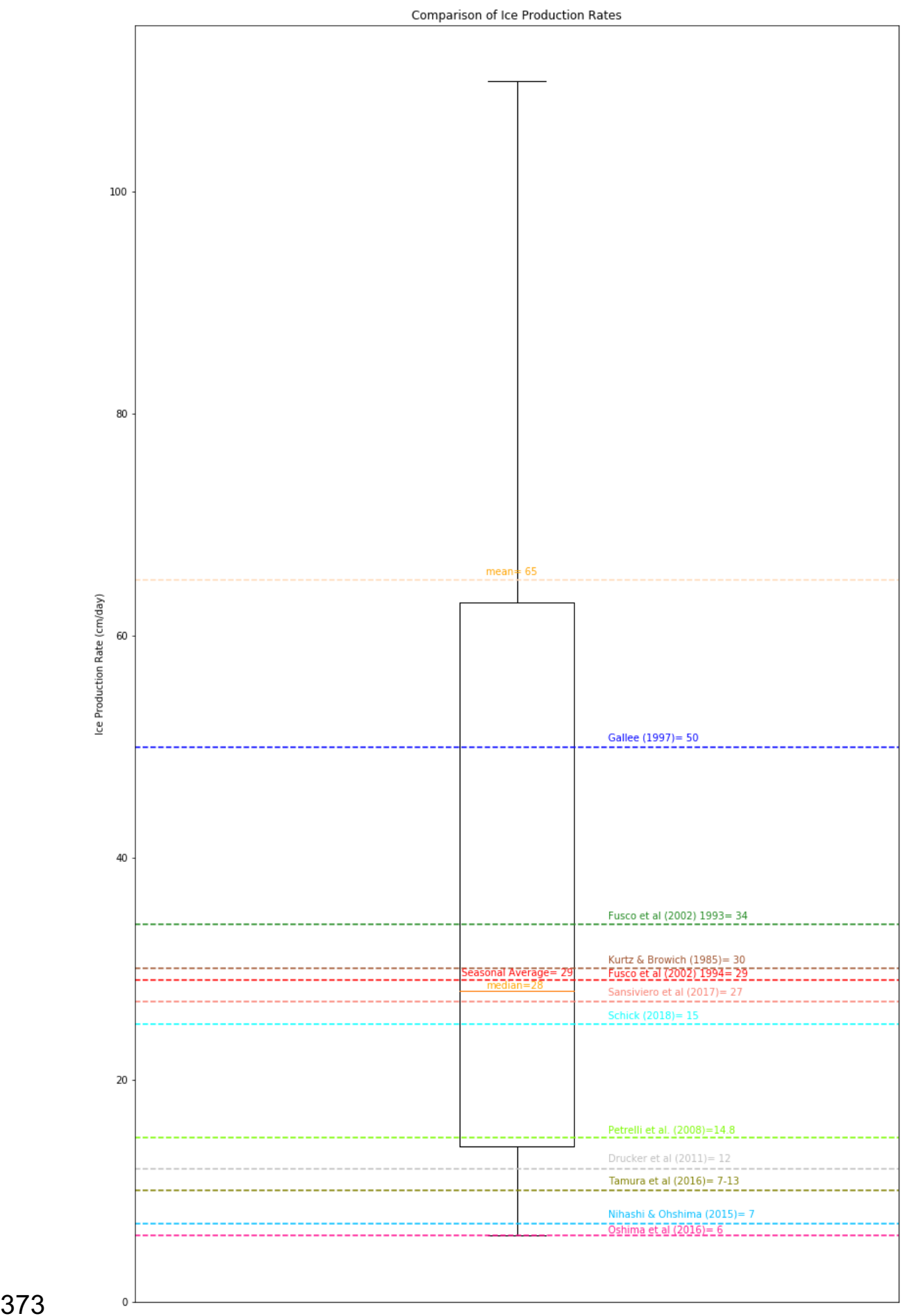

374 Supplemental Figure 5: Comparison of Ice production rates. This box and whisker plot shows the 375 production rates calculated in this study. Station 35 , marked as an outlier is not shown, but was included 376 in the mean and median calculations. 

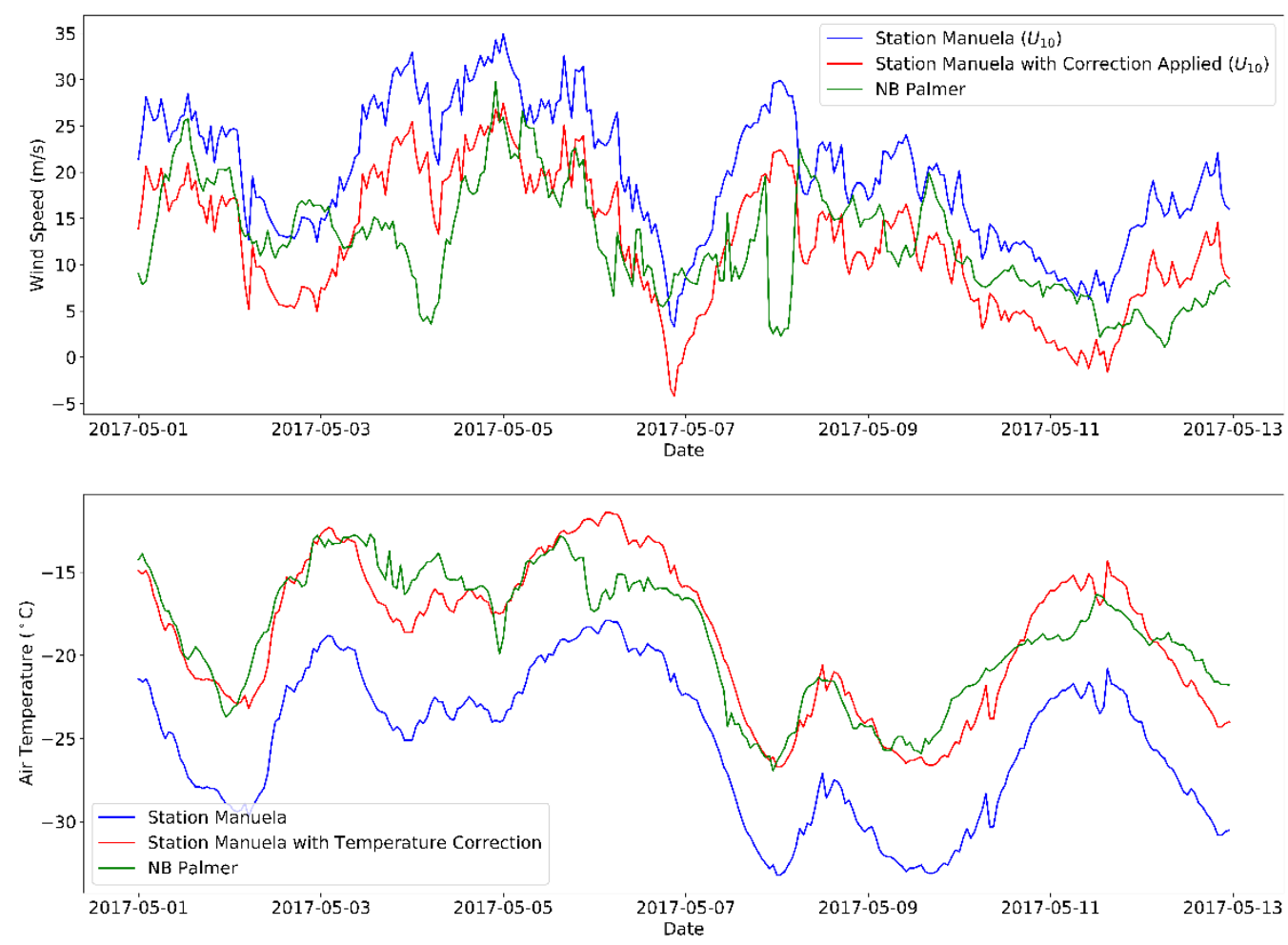

Supplemental Figure S6: The Station Manuela (blue), NB Palmer (green), and Station Manuela corrected (red) 10-meter wind speed and air temperature for the 13 days that NB Palmer was in TNBP. The air temperature correction fits the NB Palmer weather well. The wind speed correction varies between being an over and underestimate, however both the NB Palmer data and the corrected Station Manuela data average to $12.4 \mathrm{~m} \mathrm{~s}^{-1}$ indicating that in the context of a long term seasonal average, the wind correction is accurate. 